\title{
Assessment of Bank Health Level towards Profit Growth
}

\author{
Antyo Pracoyo \\ Indonesia Banking School \\ antyo@ibs.ac.id
}

Dita Putriyanti

Indonesia Banking School

dita.putriyanti@yahoo.com

\begin{abstract}
The objective of this research is to analyze the influence of Risk Based Bank Rating (RBBR) components to the growth profit banking industry in Indonesia. The sample consists of Banks which categorized as Bank Umum Kegiatan Usaha (BUKU) 4 or Banks with capital asset over 30 billion IDR. The data gathered include the period of 2011 until 2013. The technique of analysis used for this research is multiple linear regression. This research has been analyzed with EViews 7.1 program, and during the significance test it indicated that fixed effect was the most appropriate method. The result of this research shows that Non-Performing Loan has a negative and significant effect on growth profit. Loan to Deposit Ratio, Good Corporate Governance, Net Interest Margin, Capital Adequacy Ratio have a positive but no significant effect on growth profit.
\end{abstract}

Keywords: RBBR, NPL, LDR, GCG, NIM, CAR, growth profit

Tujuan dari penelitian ini adalah untuk menganalisa pengaruh dari Risk Based Bank Rating (RBBR) kepada tingkat pertumbuhan dari indystri perbankan yang dikategorikan Bank Umum Kegiatan Usaha (BUKU) 4 pada periode 2011 sampai dengan 2013. Teknik analisa yang digunakan pada penelitian ini adalah multiple linier regression. Riset telah dianalisan menggunakan EViews 7.1 program, and tes signifikansi meningikasikan bahwa fixed effect andalah metode yang paling sesuai. Hasil dari penelitian ini menunjukan bahwa Non Performing Loan mempunyai efek negatif and signifikan dalam pertumbuhan laba. Loan to Deposit Ration, Good Corporate Goverance, Net Interest Margin, Capital Adequacy Ratio mempunya efek positif tapi tidak signifikan dalam mempengaruhi pertumbuhan laba.

Kata Kunci: RBBR, NPL, LDR, GCG, NIM, CAR, pertumbuhan laba 


\section{Introduction}

Bank has an important role in the economy (Mishkin, 2013). Bank is an intermediary institution to connect party that has excessive money and those who need money and will borrow the money. Bank is the heart of economy (Darmawi, 2011). The Money will flow to the bank and it will be redistributed to economic system to grind economic activity. This process happens continuously without stopping. Thus, a bank has important roles in economy. On the other side, a bank is very sensitive to the economic changes.

Until 2014, according to the calculation of concentration ration (CR-4) in national level, our banking industry is still monopolistic (Antyo, 2016). Concentration ratio implies that top rank in terms of credit distribution in national level, in particular order, are BRI, Mandiri, BCA, and BNI.

Bank as the biggest intermediary in the economy requires specific regulations and study. (Mishkin, 2013). Since 2013, a regulator of banking is Financial Service Authority (OJK), Bank Indonesia is no longer supervisor of the banking industry. The Regulator has authority to regulate and supervise banks. All banking regulations are listed in OJK regulation. Thus, all bank can implement the regulations which is are supervised by the regulator.

The complexity of the banking industry development can trigger risks. Development of bank's assessment method is dynamic thus, assessment of bank's health level must have the development to reflect a current state of the bank and in the future (Darmawi, 2011). In 2004, there is regulation of Bank Indonesia on bank's health level with CAMELS methods, however, during the development of bank, in 2011, there is an assessment of bank's health level with Risk-Based Bank Rating (RBBR) method.CAMELS does not use risk indicators of a bank. Meanwhile, RBBR uses risk as one scoring indicator for bank health level. This study and research will use RBBR method. Argument of this study is that every bank has risk thus, they should be careful with the risk. This precaution will make bank's operational better thus bank can increase the profit.

The health level of one bank can be rated according to several indicators. One of the main indicators of the rate of bank's health can be seen from its financial report (Almilia \& Herdiningtyas, 2005; Pandia, 2012). According to PBI NoP 13/1/PBI/2011 about the rating of bank's health level, bank health level is an appraisal of bank's condition which is conducted toward risk and bank's performance. Regulator obliges banks to maintain bank's health level which implements precautionary principles and risk management in conducting the business. Banks must do self-assessment upon bank health level as regulated in $\mathrm{PBI}$. 
The Indicator of bank's health level rating according to RBBR are risk profile, good corporate governance, earning, and capital. There are 8 types of risk profile. They are a credit risk, liquidity risk, market risk, operational risk, compliance risk, strategic risk, legal risk, and reputation risk. However, this research will only use 2 types of risks there are credit risk and liquidity risk. They are chosen because they can affect the profit.

Credit risk is rated by using Non-Performing Loan. Meanwhile, liquidity risk is rated by using Loan to Deposit Ratio. Good Corporate Governance is measured by using the composite value of bank's self-assessment. Earning uses Net Interest Margin as a parameter. Capital uses Capital Adequacy Ratio as parameter. This research use those variables because those variables have strong correlation and influence on profit growth.

Bank health is the real condition of a bank (Kasmir, 2012). If a bank is healthy then it needs to be sustained, but if it's not, actions need to be taken before the situation affect other banks and Indonesia's banking industry. The healthiness of a bank will affect the ability of the bank to perform and its customer loyalty (Kasmir, 2012).

The regulator is struggling to create healthy banking system thus, each bank must obey regulation on bank's health. However, a bank is still trying to maximize profit. One of the company's objective is to make a profit (Ross,Westerfield, Jorand, Lim \& Tan 2012). Profit can be performance indicator of a bank. Profit also important as it mirrors the value of a company (Clark \& Cathey, 2011). The better profit growth is expected because it can be a parameter of better performance and management. Thus, it needs another goal to achieve, as bank healthiness.

This research will explain a relationship between the regulator of banking and the bank. Is there any regulation about a level of bank's health as one of the regulator's objectives in controlling and supervising banking? The level of bank's health is an important aspect that stakeholders must know because bank's health level is going to give an indication in the decision making of investment.

According to the explanation about banking activity, regulator's objective $(\mathrm{BI}$ and OJK), bank's profit, this research is going to explain the influence of level of bank's healthiness towards profit growth. Researcher sees this research should look into the problem in depth because, in banking, profit and level of bank's health are important factors that bank pay attention. 


\section{Literature Review}

Signalling theory is used as part that underlies this research. Signalling theory is chosen because every assessment on bank's health will give a signal, either good news or bad ones on bank's profit growth. In addition, this study also uses bank's definition, types of bank, bank's health and its assessment as well as profit growth.

Signalling Theory

Signalling theory explains how a company should give signals to financial report user. Signalling can be good news or bad news. If companies expect high growth in the future, it can be predicted from given signal (Godfrey, Hodgson, Tarca, Hamilton \& Holmes, 2010). Signalling theory explains why a company must give a push to how a company should give news to the user of the financial report. Beside it can be done by showing accouting information such as financial report, report on what it has been done by the management to realize owner's interest or other information that state the company is better than other companies. (Susilowati \& Turyanto, 2011).

Bank's Health Level

Bank's health is the interest of any related party, the owner, management, customer, and bank authority. Nevertheless, Bank's health level can be used by those parties to evaluate bank's performance in implementation of precaution principles, compliance en with regulation, and risk management (Taswan, 2010).

Assessment of Bank's Health Level: Risk profile

Based on Circular Letter No. 13/24/DPNP the year 2011 regarding bank's healthiness level, risk profile assessment is an assessment of comprehensive risk and risk management implementation quality in bank operational activity. The Risk is a threat or possibility of certain action or occurrence that might trigger impact opposite to desired objective (Pandia, 2012). A risk is a possible event that might trigger loss for the bank (Siamat, 2005).

The risk that must be assessed consists of 8 types of risks. They are a credit risk, market risk, operational risk, liquidity risk, legal risk, strategic risk, compliance risk, and reputation risk. As explained earlier, the study in this research only uses 2 types of risk which is are credit risks and liquidity risk. Credit risk can happen as a result of counterparty's failure in fulfilling its obligation. (Siamat, 2005). Risk credit can be measured with Non-Performing Loan (NPL). The higher the NPL, the lower the quality of credit of loan portfolio, thus the non-performing loan is high and the more risk that a bank has (Almilia \& Herdiningtyas, 2005; Darmawi, 2011).

Indonesia Central Bank has determined maximum limitation for NPL that is $5 \%$ in Indonesia Central Bank Regulation Number: 15/2/PBI/2013. Meanwhile, liquidity risk can 
be measured by using Loan to Deposit Ratio (LDR). Based on Indonesian Central Bank Regulation number: 15/15/PBI/2013 limitation for LDR is 78\%-92\%.

H1: Non-Performing Loan (NPL) partially has significant effect toward profit growth

The higher NPL, the possibility of the bank to face non-performing loan risk is higher (Darmawi, 2011). If a bank has high NPL thus the asset of the bank will go down thus, there will be the possibility of profit decrease and giving bad news signal in the financial report. In addition, the higher NPL will psychologically influence bank management in giving credit. They will be more prudent. Indonesia Central Bank determines $5 \%$ as the maximum limit of NPL according to Indonesia Central Bank Regulation No.15/2/PBI/2013.

H2: Loan to Deposit Ratio (LDR) partially has significant effect toward profit growth

The increase of Loan to Deposit Ratio can be caused by the increasing number of credit (Fathoni, Sasongko, \& Setyawan, 2012). If total credit increase, interest fee from credit will increase. It will be followed by increasing bank profit if bank's income increase. The increase of LDR will give a good news signal that the better bank's performance will be followed by profit growth.

H3:Good Corporate Governance (GCG) partially has significant effect toward profit growth

Good Corporate Governance (GCG) is a transparent process of company's objective, achievement, and performance (Andiri, 2006).GCG is determined based on the composite score of self-assessment which is assumed to be treated as interval data (Abelson \& Turkey, 1970) application of this practice also found in Halimatussadiyah, Sofianty, and Ermaya (2015). If a bank has low GCG composite score, it shows that the management quality or bank's operational management is good. Therefore, if the quality of bank's management is good, there will be good news signal on bank's performance that is followed by profit increase. It shows that if a bank has implemented GCG well, there will be good news to profit earned by the bank.

H4: Net Interest Margin (NIM) partially has significant effect toward profit growth

NIM is a ratio used to measure the capability of bank's management in managing its products to earn net profit income. (Pandia, 2012). If bank's capability in earning interest gets higher, profit will be higher too. It is because there is good news signal that there is an increase of in profit due to an increase of bank's interest.

H5:Capital Adequacy Ratio (CAR) partially has significant effect toward profit growth

If CAR gets higher due to increasing capital, it can be used to manage assets and increase bank's performance, followed by profit growth. Sufficient capital will give good news for profit growth. Bank of Indonesia determine CAR 8\% in PBI Nomor: 
14/18/PBI/2012 to repair bank's capability to produce income which is followed with profit growth and to increase bank's health quality.

\section{Methods}

This research is an applied study from the previous study using RBBR method. Data on this research use period 2011-2013. This period is chosen because PBI about bank's health with RBBR method was published in 2011. Furthermore, the time frame uses 3 months period. It is aimed to see the fluctuation of bank's profit growth on every quarter period

This research is using secondary data in the for of panel data. Panel data is a combination of time series and cross-section data (Winarno, 2011). The Source of data is reports published by bank and Otoritas Jasa Keuangan.Population in this research is all bank that still conducts operational activity in Indonesia. There are 120 banks. The sampling technique uses purposive sampling. Purposing sampling is a technique to determine sample with certain consideration (Sugiyono, 2012). Sampling criteria are as follow:

1. The sample is registered banks and has an operational permit from Bank of Indonesia.

2. The sample is banks that is are included in Common Bank Business Unit criteria 4 (BUKU 4) in 2011-2013. This criteria covers Bank with capital not less thantRp30.000.000.000.000,00 (thirty trillion Rupiah).

3. The sample has financial report quarterly in 2011-2013

4. The sample has self-assessment Good Corporate Governance report between 20112013.

The reason why bank sample is a bank in BUKU 4 because a bank with BUKU criteria has bigger potential than other banks, bigger influence toward other banks as well as the economy of Indonesia, and significant systematic risk. Banks in BUKU 4 category in 2011-2013 are PT Bank Mandiri (Persero) Tbk, PT Bank Rakyat Indonesia (Persero) Tbk, PT Bank Central Asia Tbk and PT Bank Negara Indonesia (Persero) Tbk.

Based on data in 2013, a bank in BUKU 4 has a bigger influence and market in terms of financial and network compared to 120 common banks in Indonesia. According to financial capability, BUKU 4 can possess $36 \%$ in capital, $45 \%$ assets, $48 \%$ third party fund, $44 \%$ credit, $57 \%$ profit. Based on network capability, BUKU 4 has 55.017 units of bank office and 90.986 million bank account. The stated model can be portrayed in the following equation. 


$$
P L_{i t}=\beta_{0}+\beta_{1} N P L_{i t}+\beta_{2} L_{D R}+\beta_{3} G C G_{i t}+\beta_{4} N_{I M}+\beta_{5} C A R_{i t}+\varepsilon_{i t}
$$

\begin{tabular}{|l|ll|}
\hline $\begin{array}{l}\mathrm{PL} \\
\beta_{\mathrm{it}}=\text { Profit Growth }\end{array}$ & NIM & $=$ Net Interest Margin \\
$\beta_{1} \quad \beta_{2}, \quad \beta_{3} \ldots=$ Indepentdent $\quad$ Variable & CAR & $=$ Capital Adequacy Ratio \\
$\begin{array}{l}\text { Coefficient } \\
\text { NPL = Non Performing Loan }\end{array}$ & $\mathrm{i}$ & $=$ Error Estimation \\
LDR = Loan to Deposit Ratio & $\mathrm{t}$ & $=$ Cross Section Identifiers \\
GCG = Good Corporate Governance & & $=$ Time Series Identifiers \\
\hline
\end{tabular}

\section{Result and Discussion}

The sequence of systematic discussion are, as follows: descriptive statistic, data panel regression determination, normality examination, classical hypothesis examination, double linear regression analysis and managerial implication.

Descriptive statistic of this research consists of mean, median, maximum, minimum, deviation standard, skewness, and kurtosis. According to Chow test, the data model of this research is categorized as Fixed Effects Model. Based on normality examination through Jarque-Bera Test, the $p$-value $=0.548771$ above $\alpha=0.05$ and it can be inferred that data has been normally distributed. In addition, there has been the multicollinearity test concluded that there are no any multicollinearity elements in this research. In this examination, the first autocorrelation is conducted by examining DurbinWatson Stat at the result of regression estimation. The result of autocorrelation examination shows that Dubin-Watson score is 2.153982 , thus it can be concluded that it is free from autocorrelation problem because it's a 1.54-2.46 limit. In this research, heteroscedasticity examination is conducted by using Park Test. The result of Park Test shows that there is a coefficient of probability from each independent variable as big as 0.05 until it can be concluded that this research is free from heteroscedasticity problem.

\section{Model Examination}

\section{Adjusted R-Squared}

Adjusted R-Squared is a statistic value that can be used to measure how far model used to relate independent variable and dependent variable in estimating regression equation. Based on double regression equation above, Adjusted R-Squared is 0.892537 or $89.2537 \%$.It shows that NPL, LDR, GCG, NIM, and CAR can explain the influence to profit growth up to $89.2537 \%$. The rest $(10.7463 \%)$ is explained by other variables that is are not explained in this research's model. Other drivers can be in the form of assessment of bank's health which is not outside the scope of this research. This research only uses some assessment indicators for the level of bank's health according to Circular Letter No. 13/24/DPNP. 
F Test (Simultaneous)

$\mathrm{F}$ test is used to examine whether all independent variable jointly has significant influence toward dependent variable. According to regression table of $\mathrm{F}$ test, F-statistic is 0.000000 . With significant value in the amount of 0.05 , F-statistic is smaller than 0.05 . It shows that NPL, LDR, GCG, NIM, and CAR simultaneously give significant influence to profit growth.

\section{Hypothesis Examination and Explanation:}

\section{Impact of Non-Performing Loan to profit growth}

The Impact of Non-Performing Loan (NPL) toward profit growth shows a significant and negative result. It is aligned with the result of regression coefficient in the amount of 2.015294 and probability 0.0000 which is smaller than significance level 0.025 . Therefore, the higher NPL, the worse potency of bank's credit risk. If it is not anticipated soon with steps to anticipate NPL level, it will waste bank's business source. Therefore, it will disturb cycle of saved society's money and it can affect bank's profit. Besides the amount of NPL can trigger bigger bank's opportunity cost until it reduces bank's capability to earn a profit.

Moreover, If NPL is increasing, the higher cost of the bank due to the provision of for loan losses and cost to settle bad debts.Therefore, the increasing NPL, the bigger possibility of bank's profit decrease. Higher NPL will influence bank management psychologically in distributing credit to be more prudent. Bank is going to pay attention not only to quantity in credit distribution but also focusing on quality of credit distribution. This is due to because NPL is a ratio of bank assessment that is watched by society in general and regulator. Thus, NPL has significant influence toward profit growth. The Result of this research supports research conducted by Fathoni (2012), Putri (2010), and Doloksaribu (2011) that states NPL has a negative and significant influence on profit growth.

\section{Loan to Deposit Ratio influence to Profit Growth}

Loan to Deposit Ratio (LDR) to profit growth shows a positive and insignificant result. It is in line with the result of regression coefficient as big as 0.051471 and probability as big as 0.1278 which is bigger than the significance level, 0.025 . LDR is bank's capability in the case of liquidity. One of the reasons why LDR increase is because the increasing amount of credit distributed by the bank. The more increasing the credit is, the more profit growth will get positive influence.

However, LDR calculation uses total credit including non performing loan thus, it may cause the decrease of profit if non-performing loan increases. Because of the nature, LDR insignificantly influences profit growth. In the credit distribution, the bank must count Risk Weighted Asset (ATMR) as one of evaluation on how bank's credit is. Higher bank's 
ATMR credit indicates that quality of bank credit keeps decreasing and relate to profit growth. Below is total data of ATMR Credit in BUKU 4 year 2011-2013:

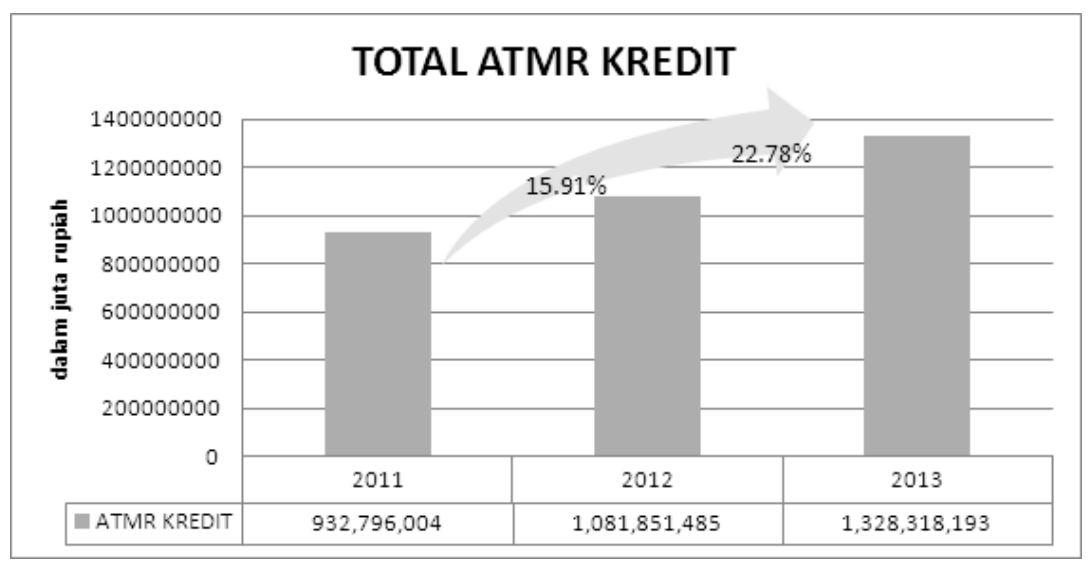

Figure 1. Bank Financial Report

According to data above, it can be seen that total amount of Risk Weighted Asset (ATMR) Credit in BUKU 4 category year 2011-2013 is always increased every year. It shows that quality of credit owned by the bank was going down and it potentially decreased the profit.The data also shows that increase of LDR was followed by an increase of Risk Weighted Asset thus, there is a positive yet insignificant influence of LDR to profit growth. The result of this research supports research conducted by Fathoni (2012), Barus (2011), and Doloksaribu (2011) that states LDR has an insignificant influence to profit growth.

\section{The Effect of Good Corporate Governance to Profit Growth}

Good Corporate Governance effect towards profit growth shows a positive effect but not significant result. It is in line with the coefficient of regression which is 0.005327 and probability which is 0.4847 and it is bigger than signficance level that is 0.025 . Calculation of Self Assessment Good Corporate Governance composite value comprises of 11 aspects of assessment. According to the assessment, there is no assessment that bases on bank business activity which influences profit. For example credit distribution, third party funding, foreign currency, etc. It shows that GCG is only a medium for a bank to act professionally and carefully in managing it business for the sake of shareholder's interest and other bank stakeholders. There is no certain assessment in bank business activity that influence profit in GCG assessment, it makes GCG insignificantly influence profit growth.

Bank might have conducted GCG well but it does not influence profit. This result might due to other factors that influence profit. Good management will have positive impacts to bank's profit, however, it is not the primary thing because there are still other 
factors such as an economic condition of a country, bank's competition, customer, etc. Therefore, GCG is not the primary factors that influence bank's profit even though bank must still pay attention to GCG in managing its business activity.

Net Interest Margin to Profit Growth

Net Interest Margin (NIM) influences to profit growth shows positive and not significant result. It is appropriate with the result of coefficient of regression, 0.706456 and probability, 0.1338 that is bigger than significance level of 0.025 . If NIM increase, it will positive impact to profit growth. It is because there is an increase of interest based income, thus there is an increase of bank's profit.

NIM does not affect significantly to profit growth. It shows that bank has not managed its productive assets to its maximum level to earn interest based income. Net profit income is an aggregate between interest based income and interest cost. A small aggregate might be caused by the increase of BI Rate and inflation thus interest cost gets increased and caused bank's opportunity to earn maximum profit from the productive active decline. The following figure is based on data of BI Rate and Inflation between 20112013

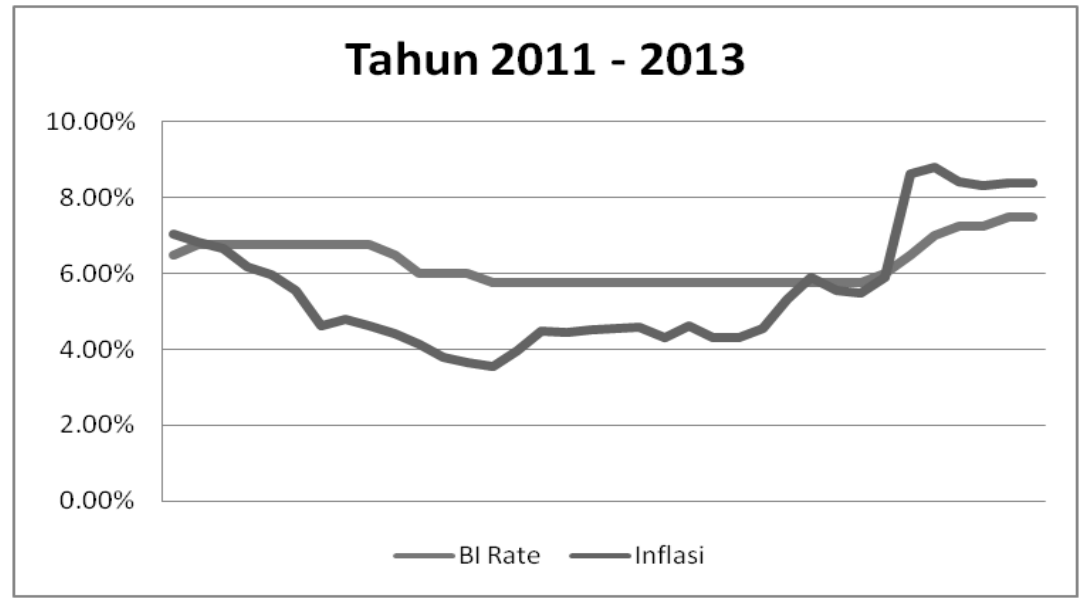

Figure 2. Inflation and BI Rate from Bank Indonesia

Above graphic shows movement of BI Rate and Inflation in Indonesia from 2011 until 2013. BI Rate and Inflation always increase every year. It becomes a reason why interest based income does not significantly influence profit growth which is caused by increasing interest fee thus, there is declining the opportunity for a bank to gain maximum profit from its productive assets.

Today, expansion of bank service as payment of electricity and telephone bill, transfer, clearing, Real Time Gross Settlement (RTGS), export-import funding transaction also affect bank's profit considering customer uses bank service not only as the place to save the money but also enjoying other facilities provided by the bank. Below are data of 
interest based income and commission, fee, provision, and administration fee in the bank with BUKU 4 category year 2011-2013.

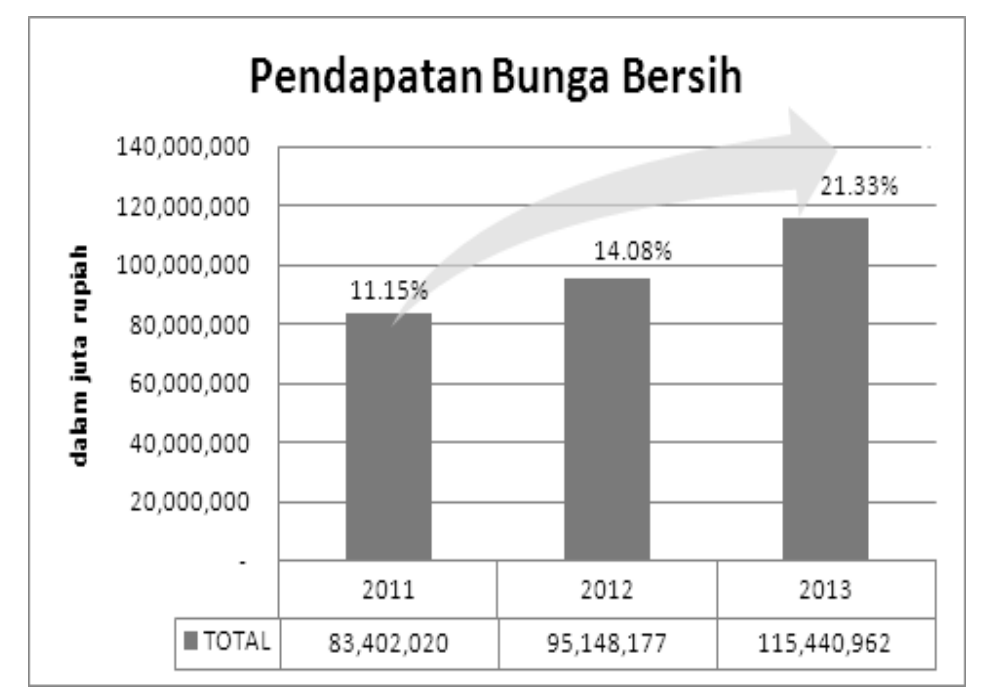

Figure 3. Net Interest Margin from Bank's Financial Report

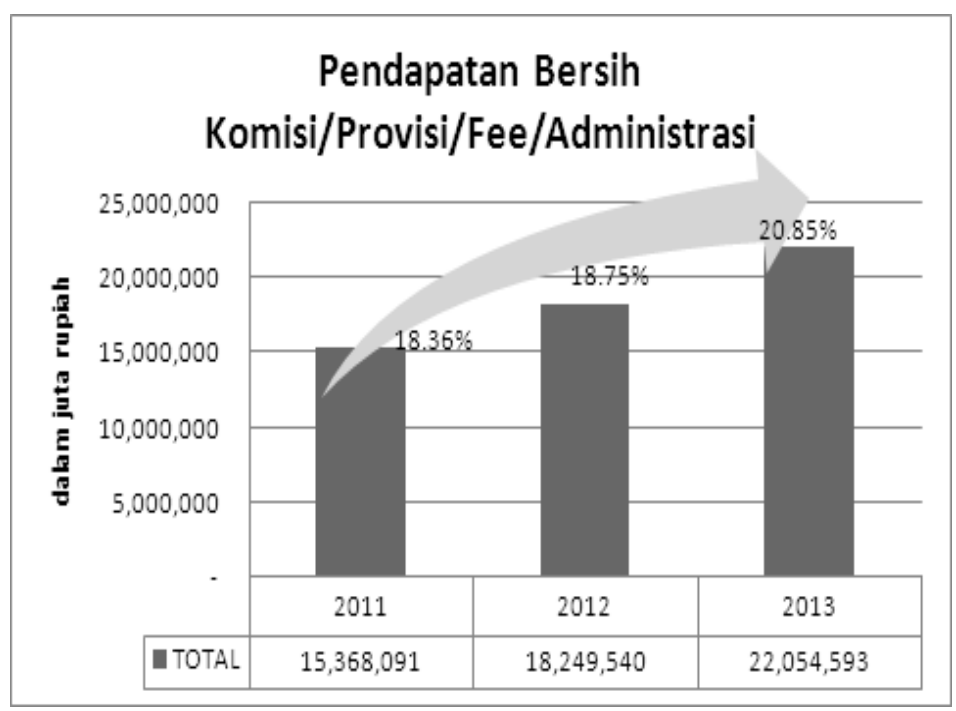

Figure 4.. Interest Income from Bank's Financial Report

According to above data, the growth of commission, provision, fee, administration income in BUKU 4 during 2011-2013 face higher increase than interest based income.It shows that interest based income is not the only income that potentially increase profit growth. There is still other income that might affect profit growth. Therefore, NIM affects insignificantly to profit growth. The result of this research supports the result of research by Putri (2010) and Doloksaribu (2011) which states that NIM affects insignificantly to profit growth. 


\section{Influence of Capital Adequacy Ratio to Profit Growth}

The influence of Capital Adequacy Ratio (CAR) to profit growth shows positive and insignificant result. It is in line with the coefficient of regression in the amount of 0.179364 and probability equal to 0.2619 which is higher than significance level that is 0.025 . CAR is a ratio of capital adequacy that shows bank capability in maintaining owned capital and bank's management capability in identifying, measuring, supervising, and controlling risks that emerge, which it might affect the amount of capital owned by the bank. CAR condition in a bank with BUKU 4 category in 2011-2013 shows very good condition, where the average of CAR is $16.089 \%$. That is a very good thing because the minimum standard that CAR has implemented is $8 \%$. This condition explains that bank is not optimizing available capital for activity that earns profit because it must calculate the possibility of ATMR's increase.It causes CAR not becoming a significant factor to bank's profit growth.This finding aligns with Barus (2011) that found CAR has an insignificant effect towards profit growth. However, it contrasts the result from Hapsari (2004), Putri (2010) and Fathoni (2012).

Another factor that might contribute to the finding is increasing $\mathrm{BI}$ Rate and inflation in 2011-2013 and global influence especially policy of The Fed such as quantitative easing that makes bank must be able to maintain and compete. When cost is increasing and interest rate keeps increasing, the bank needs enough capital to stand. Therefore, when capital is increasing, it might not directly affect profit bank.It is because bank's capital is needed as a basis for doing bank's activity and fulfillment of regulation such asCapital Adequacy Ratio (CAR) and statutory reserves.

This research supports result of research conducted by Barus (2011)that states CAR does not significantly affect profit growth.

\section{Dominant Independent Variable towards Profit Growth}

Based on this research, the most dominant independent variable to dependent variables is NPL. It is shown by the result of linear regression analysis that NPL is the only factor that influences significantly to profit growth.Meanwhile, LDR, GCG, NIM, and CAR does not significantly influence profit growth.

Credit is one of main bank business activity, thus, the bank must maintain distributed credit from disturbing bank's stability and economy of Indonesia. High NPL does not only disturb profit of bank but also disturb credibility of the bank. High NPL reflects that bank is not maximum in managing productive assets. According to PBI Number: 14/15/PBI/2012 on assessment of quality of bank's assets, banks are required to calculate allowance for assets (PPA) towards productive assets and non-productive assets, with condition as follows:General reserves at least equal to $1 \%$ ) of productive assets with a 
substandard quality; $5 \%$ (five percent) of assets with special attention, after being deducted with the value of collateral; $15 \%$ (fifteen percent) of assets with sub-standard quality after being deducted with the value of collateral; $50 \%$ (fifty percent) of assets classified as doubtful after after being deducted with the value of collateral; $100 \%$ (one hundred percent) of assets classified with bad quality after being deducted with the value of collateral.

Based on PBI, if a bank has high NPL, the bank must bigger productive assets. Banks are required to have reserves with a minimum amount of PPAP as already determined. Reserves owned by the bank is called allowance for impairment losses. Allowance for impairment losses is established when the carrying value of financial assets after impairment is less than the carrying value early. The higher the Allowance for impairment losses causes the higher you have backed up. This will cause the business of banks is reduced due to the banks must reserve to NPL, as a result of what happens is there is a potential decline in bank earnings

Credit that has headed to NPL needs attention in order not to be worse or bring losses. To fix the quality of credit, it must be studied in detail condition that debtor face and a treatment must be done according to the condition of each debtor. According to PBI Nomor: 14/15/2012 about Assessment of quality of bank, there are regulation about credit restructuration that can be done by bank as a way to mitigate NPL that is done by: decreasing credit interest; extending credit's time span; reducing arrears of credit's interest; addition of credit facility; and/or conversion of credit into temporary equity.

Besides, there are others methods. They are rescheduling and reconditioning. If restructuring, rescheduling and/or reconditioning but, debtor can't accomplish its obligation, the bank can sell the credit as the last option to other party or for a closure of collateral.

\section{Managerial Implication}

\section{Banking}

Simultaneously, NPL, LDR, GCG, NIM, CAR influence profit growth significantly, therefore, in fulfilling stakeholders' expectation that is bank can grow healthy and give optimum profit, bank's health level management must base on Risk Base Bank Rating (RBBR). It has to get attention and conduct well.

Specifically, bank's business activity should pay attention to Non-Performing Loan (NPL) because it has a significant role in profiting growth thus, professional effort in managing NPL is important to keep profit growth healthily. To repair quality of credit, the bank must 
know the problem that debtor is facing. It can do a restructuring, rescheduling and/or reconditioning as well as foreclosure of collateral or sell the credit to other people.

\section{Regulator of Bank}

Simultaneously, it can be seen that assessment on bank's health level withRisk Based Bank Rating (RBBR), especially NPL, LDR, GCG, NIM, CAR variables affects significantly to profit growth. Thus, in terms of role regulator in guiding and monitoring bank's activity, an especially bank with BUKU 4 category can focus on above variables in order for the bank to grow healthily and earn an optimum profit.

This research only uses 5 independent variables of bank's health level with Risk Based Bank Rating (RBBR) method according to Appendix I SE No. 13/24/DPNP and time period of this research is 3 years with bank in BUKU 4 category as sample. Thus, writer give suggestion for future research to expand the time period more than 3 years and use others independent variables such as market risk, operational risk, and others factors to enrich the study.

\section{Conclusion}

According to the analysis of research, it can be inferred that bank's health level really influence profitability level of the bank in BUKU 4 category. The result indicated that, partially, Non-Performing Loan (NPL) has significant influence to profit growth because credit is the biggest bank's business unit thus, there is a problem with credit that will influence in bank's profit. Partially, Loan to Deposit Ratio (LDR) does not have significant influence to profit growth. It is because LDR calculation for used total credit including nonperforming loan. It may cause the potential decline of profit for the bank if non-performing loan increases. Partially, Good Corporate Governance (GCG) does not have a signficant influence to profit growth. It is because GCG is an internal process of bank management in handling carefully and professionally. However, profit is not only about GCG but also others influencing external factor.Partially, Net Interest Margin (NIM) does not have a signficant influence to profit growth. It is because $\mathrm{BI}$ rate and inflation that cause increasing interest rate and the use of other bank service increases thus, net income from commission/ provision/fee/administration is increasing. Partially, Capital Adequacy Ratio (CAR) does not have a signficant influence to profit growth. It happens because the bank is not optimizing available capital that can earn a profit because it must calculate the possibility of an increase in ATMR.

Simultaneously or together, NPL, LDR, GCG, NIM, CAR has significant influence on profit growth. If the bank can manage NPL, LDR, GCG, NIM, CAR well and following the applicable provision that precaution thus, it will affect profit growth. The most dominant variable that influences profit growth is NPL. It is because credit is the main business 
activity of bank. If distributed credit bank is problematic and managed badly, it will affect bank's profit significantly.

\section{References}

Abelson, R.P. and Turkey, J.W. (1970). Efficient Conversion of Non-Metric Information into Metric Information the Quantitative Analysis of Social Problems, Reading MA: Addison Wesley

Almilia, L. S., \& Herdiningtyas, W. (2005). Analisis Rasio Camel Terhadap Prediksi Kondisi Bermasalah Pada Lembaga Perbankan Periode 2000-2002. Jurnal Akuntansi and Keuangan , 7 (2), 1-27.

Bank Indonesia. (2001). Peraturan Bank Indonesia. Nomor 3/21/PBI/2001 tentang Kewajiban Penyediaan Modal Minimum Bank Umum.

Bank Indonesia. (2004). Peraturan Bank Indonesia. Nomor 6/10/PBI/2004 tentang Sistem Penilaian Tingkat Kesehatan Bank Umum.

Bank Indonesia. (2005). Surat Edaran Bank Indonesia. Nomor 7/3/DPNP tentang Penilaian Kualitas Aktiva Bank Umum.

Bank Indonesia. (2011). Peraturan Bank Indonesia. Nomor 13/1/PBI/2011 tentang Tingkat Kesehatan Bank Umum.

Bank Indonesia. (2011). Surat Edaran Bank Indonesia. Nomor 13/24/DPNP tentang Penilaian Tingkat Kesehatan Bank Umum.

Bank Indonesia. (2012). Peraturan Bank Indonesia. Nomor 14/14/PBI/2012 tentang Transparansi and Publikasi Laporan Keuangan.

Bank Indonesia. (2012). Peraturan Bank Indonesia. Nomor 14/15/PBI/2012 tentang Penilaian Kualitas Aset Bank Umum.

Bank Indonesia. (2012). Peraturan Bank Indonesia. Nomor 14/18/PBI/2012 tentang Kewajiban Penyediaan Modal Minimum Bank Umum.

Bank Indonesia. (2012). Peraturan Bank Indonesia. Nomor 14/26/PBI/2012 tentang Kegiatan Usaha and Jaringan Kantor Berdasarkan Modal Inti Bank.

Bank Indonesia. (2013). Peraturan Bank Indonesia. Nomor 15/2/PBI/2013 tentang Penetapan Status and Tindak Lanjut Pengawasan Bank Umum Konvensional.

Bank Indonesia. (2013). Peraturan Bank Indonesia. Nomor 15/15/PBI/2013 tentang Giro Wajib Minimum Bank Umum Dalam Rupiah and Valuta Asing Bagi Bank Umum Konvensional

Bank Indonesia. (2013). Surat Edaran Bank Indonesia. Nomor 15/15/DPNP tentang Pelaksanaan Good Corporate Governance bagi Bank Umum. 
Barus, R. S. (2011). Pengaruh Rasio Keuangan CAMELS Terhadap Pertumbuhan Laba pada Bank Umum Swasta Nasional yang Terdaftar di BEI tahun 2004-2010. Skripsi. Universitas Atma Yogyakarta.

Andiri, M. A. (2006). Good Corporate Governance Konsep and Penerapannnya dalam Konteks Indonesia (2nd ed.). Jakarta: PT Ray Indonesia.

Darmawi, H. (2011). Manajemen Perbankan. Jakarta: PT Bumi Aksara.

Doloksaribu, T. A. (2011). Pengaruh Indikator Kesehatan Bank Terhadap Pertumbuhan Laba Perusahaan Perbankan Go Public. Skripsi. Universitas Brawijaya.

Fathoni, M. I., Sasongko, N., \& Setyawan, A. A. (2012). Pengaruh Tingkat Kesehatan Bank Terhadap Pertumbuhan Laba Pada Perusahaan Sektor Perbankan. Jurnal Ekonomi Manajemen Sumber Daya, 13 (1), 15-25.

Godfrey, J. , Hodgson, A., Tarca, A., Hamilton, J., \& Holmes, S. (2010). Accounting Theory (7th ed.). Australia: John Wiley \& Sons.

Gujarati, D. N. (2007). Dasar-dasar Ekonometrika (3rd ed.). Jakarta: Erlangga.

Halimatusadiah, E; Sofiyanti, Diamonalisa; Ermaya, H.N (2015) Effects of the Implementation of Good Corporate Governance on Profitability. European Journal of Business and Innovation Research, 3(4), 19-35.

Hapsari, N. (2004). Pengaruh Tingkat Kesehatan Bank Terhadap Pertumbuhan Laba Masa Mendatang pada Perusahaan Sektor Perbankan yang Terdaftar di Bursa Efek Jakarta. Skripsi. Universitas Diponegoro.

Harahap, S. S. (2012). Teori Akuntansi (revisi ed.). Jakarta: PT Raja Grafindo Persada. Hendriksen, E. S., \& Breda, M. F. (2002). Teori Akunting (5th ed.). (S. Lyndon, Penyunt.) Tangerang: Interaksa.

Kasmir. (2008). Analisis Laporan Keuangan. Jakarta: PT Raja Grafindo Persada.

Kasmir. (2012). Manajemen Perbankan (revisi ed.). Jakarta: PT Raja Grafindo Persada.

Mishkin, F. S. (2013). The Economics of Money, Banking, and Financial Markets (10th ed.). England: Pearson.

Nur, A. R., \& Syah, S. (2013). Analisis Pengaruh Operating Efficiency and Capital Adequacy Ratio Terhadap Laba Bersih Pada PT Bank Rakyat Indonesia (Persero) Tbk. ASSET, 3 (2), 116-129.

Pandia, F. (2012). Manajemen Anda and Kesehatan Bank. Jakarta: PT Rineka Cipta.

Putri, E. Y. (2010). Analisis Pengaruh CAMEL Terhadap Pertumbuhan Laba pada Perbankan yang Terdaftar di BEI Periode 2005-2007. Skripsi. Universitas Sebelas Maret. 
Putri, I. D., \& Damayanthi, I. G. (2013). Analisis Perbedaan Tingkat Kesehatan Bank Berdasarkan RGEC Pada Perusahaan Perbankan Besar and Kecil. E- Jurnal Akuntansi Universitas Udayana ,483-496.

Ross, S. A., Westerfield, R. W., Jorand, B. D., Lim, J., \& Tan, R. (2012). Fundamental of Corporate Finance (Asia Global ed.). Singapore: Mc Graw Hill.

Schroeder, R. G., Clark, M. W., \& Cathey, J. M. (2011). Financial Accounting Theory and Analysis: Text and Cases (10th ed.). United States of America: John Wiley \& Sons.

Siamat, D. (2005). Manajemen Lembaga Keuangan Kebijakan Moneter and Perbankan (5th ed.). Depok: Fakultas Ekonomi Universitas Indonesia.

Simatupang, S. U. (2010). Pengaruh Penilaian Kesehatan Bank Terhadap Pertumbuhan Laba pada BPR di Sumatera Utara. Skripsi. Universitas Sumatera Utara.

Sugiyono. (2012). Metode Penelitian Kuantitatif Kualitatif and $R \& D$. Bandung: Alfabeta. Susilowati, Y., \& Turyanto, T. (2011). Reaksi Signal Rasio Profitabilitas and Rasio Solvabilitas Terhadap Return Saham Perusahaan. Dinamika Keuangan and Perbankan, 3 (1), 17-37.

Suwardjono. (2011). Teori Akuntansi (3rd ed.). Yogyakarta: BPFE.

Taswan. (2010). Manajemen Perbankan Konsep, Teknik \& Aplikasi (2 ${ }^{\text {nd }}$ ed.). Yogyakarta: UPP STIM YKPN.

Undang-undang Republik Indonesia. Nomor 10 Tahun 1998 tentang Perubahan atas Undang-undang Nomor: 7 Tahun 1992 tentang Perbankan.

Winarno, W. W. (2011). Analisis Ekonometrika and Statistika dengan EViews. Yogyakarta: STIM YKPN 